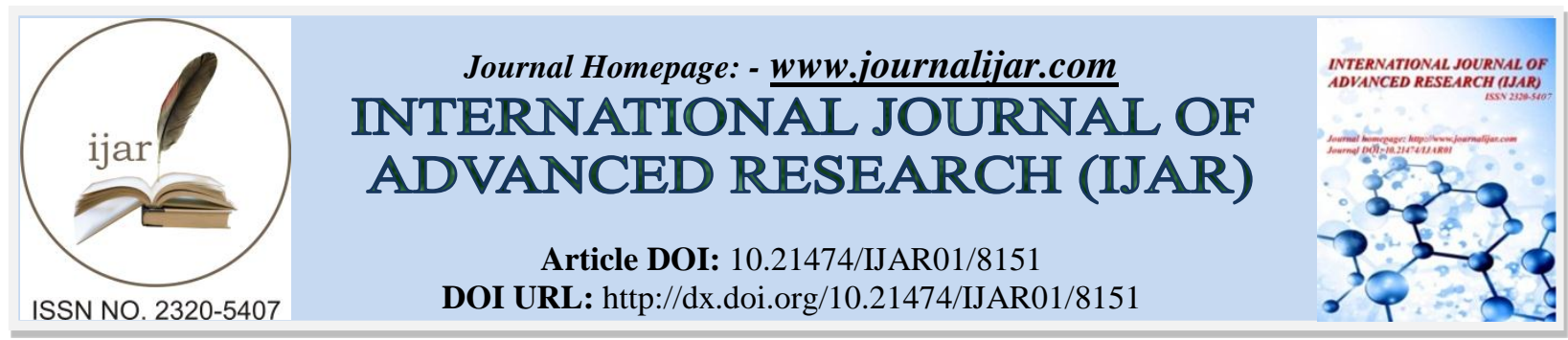

RESEARCH ARTICLE

\title{
ANTIDIABETIC AND WOUNDS HEALING ACTIVITIES OF ECLIPTA PROSTRATA (ASTERACEAE) LEAVES.
}

\section{Ampa Raoul $^{1,2}$, Morabandza Cyr Jonas ${ }^{2}$, Samba Matoko Christevy Rommelle ${ }^{1}$, Elion Itou De Garde Romaric $^{2}$, Diatewa Martin ${ }^{2}$ and Abena Ange Antoine ${ }^{2}$.}

1. laboratory of pharmacodynamics and experimental physiopathology (12pe) of the faculty of science and technology, marien university ngouabi.

2. laboratory of biochemistry and pharmacology, faculty of health sciences, marien university ngouabi.

\section{Manuscript Info}

….......................

Manuscript History

Received: 04 October 2018

Final Accepted: 06 November 2018

Published: December 2018

Keywords:

Eclipta prostrata, antidiabetic, wound, streptozotocin, rat.

\section{Abstract}

This work aims to evaluate the antidiabetic and wounds healing activities of the leaves extract of Eclipta prostrata. Antidiabetic activity was evaluated respectively in normal and hyperglycemic rats by overdose of glucose $10 \%$ at $3 \mathrm{~g} / \mathrm{kg}$ orally and, in the rat made diabetic of type II by intravenous injection of the streptozotocine $45 \mathrm{mg} / \mathrm{kg}$. The wound healing activity was evaluated by incision of approximately $1 \mathrm{~cm}^{2}$ on the beforehand shaven back of rat. The obtained results revealed that the aqueous extract $(200,400$ and $800 \mathrm{mg} / \mathrm{kg}$ ) descrease significantly the peak of glycemia compared to the obtained with distilled water in the rats, $30 \mathrm{~min}$ after the overdose of glucose. This decrease continues until the $5^{\text {th }}$ hour and, the extract effect occurs at different hours according to the doses. In the same way, the ointment A and $\mathrm{B}$, respectively with aqueous and hydro-ethanolic extract added with vaselin, significantly reduce the wounds diameters. The wounds were completely healed after 14 day by the ointment against 18 day for vaselin and cicatryl. These results justify the use of E. prostrata in traditional medicine against diabetes and wounds.

Copy Right, IJAR, 2018,. All rights reserved.

\section{Introduction:-}

Diabetes is a metabolic condition characterized by permanent hyperglycemia resulting from either lack of insulin secretion by endocrine pancreatic $\beta$ cells, or insulin action or both (Hajzadeh et al., 2011). In Africa, the epidemiologic data of the diabetes are estimated at 14 million in 2011 and in 2030 this number will reach 28 million diabetic (Sambo, 2011). In the Republic of Congo, according to Diabaction Association of Congo, the prevalence is estimated at 7\% (ADC, 2015). Unsupported diabetes leads to several complications (neurological, nephrological, metabolic, cardiovascular...), including various amputations due to difficulties in healing wounds, sometimes very negligible at first. These complications affect the patient life or lead to death if treatment does not occur in time. In developing countries, the prevalence is around 20 to $30 \%$ (Grimaldi, 1997), with the outlook for 2025 moving towards a global prevalence of 300 million adults with diabetes. The modern drug exists, but no treatment regimen is perfect, because in the long term, there are several side effects and a gradual decrease in the effectiveness of treatment (Nissen et al., 2007; Nissen et al., 2010). In response, WHO, in resolution AFR / RC50 / R3 of 31 August 
2000, encouraged African countries to develop regional strategies on traditional medicine to undertake research on medicinal plants in animal health delivery systems. Health care. In 2008, diabetologists came to the conclusion that a therapeutic supplement consisting of plant extracts is necessary to optimize the treatment of diabetes (WHO, 2008). Thus, Eclipta prostrata, a plant widely used in traditional African medicine has been studied. Several healing virtues have been attributed to it and some have been scientifically proven, including: analgesic activity (Dithala et al., 2012), the antioxidant effect (Mohamed and Nalini Devi, 2015), anti-inflammatory activity (Tewtrakul et al., 2011). In Congo, this plant is used for the treatment of diabetes and also very famous for the healing of wounds even the most serious (Ahombo et al., 2012). In addition, no scientific study has so far confirmed these effects. Therefore, this study was undertaken to justify its use in traditional medicine for the treatment of diabetes and wound healing.

\section{Material and methods:- Plant material}

Fresh leaves of Eclipta prostrata were collected at Talangai (Brazzaville) in March 2017. The plant was authenticated by National Research in Exacts and Naturals Sciences Institute (IRSEN) and compare with the sample $\mathrm{N}^{\mathrm{o}} 1556$ collected by P. SITA on April 22, 1967. The collected leaves were previously washed and air dried at a temperature of $25^{\circ} \pm 1^{\circ} \mathrm{C}$ during 14 days in the laboratory of the Faculty of Science and Technology and, grounded into powder thanks to a Wood mortar.

\section{Animal material}

Wistar male rats of 3 months old weighing between 200 and $300 \mathrm{~g}$ were used. They were kept under standard conditions (12 hours of lighting and 12 hours of darkness, water and food were given to them at will).

\section{Preparation of extracts}

Two types of extracts were preparing for experimentations. Respectively, $200 \mathrm{~g}$ of leaves powder were boiled for 20 minutes in $2000 \mathrm{ml}$ of distilled water and, in $1600 \mathrm{ml}$ of ethanol added to $400 \mathrm{ml}$ of distilled water. After cooling, the mixture was filtered using a hydrophilic cotton and a filter paper. The filtrate was concentrated using a rotavapor and then dried at $40^{\circ} \mathrm{C}$ until the water was exhausted. $30 \mathrm{~g}$ of dry extract were obtained, corresponding to the yield of $15 \%$ with aqueous extract and $37.50 \mathrm{~g}$ of dry extract as a yield of $18.75 \%$ extraction.

\section{Induction of type II diabetes}

Type II diabetes was induced by injection of streptozotocin (SIGMA, Chemical-Co, USA), previously dissolved in $0.9 \%$ sodium chloride solution. Male rats were injected with streptozotocin through the dorsal vein of the penis after diethyl ether anesthesia at $45 \mathrm{mg} / \mathrm{kg} .72$ hours after rats with moderate hyperglycemia ranging from 1.50 to $2.80 \mathrm{~g} / \mathrm{l}$ after a 16 hours fasting were selected as type II diabetics (Tedong et al., 2007).

\section{Anti-hyperglycemic effect of the aqueous extract in normal rats.}

The method described by Metais et al., (1980) was used. Normal rats divided into five groups of five rats each one received orally respectively, $10 \mathrm{ml} / \mathrm{kg}$ of distilled water (negative control); $5 \mathrm{mg} / \mathrm{kg}$ of glibenclamide (positive control); 200, 400 and $800 \mathrm{mg} / \mathrm{kg}$ of aqueous extract of E. prostata 1 hour before the $10 \%$ glucose overdose. Glycemic level was taken $1 \mathrm{~h}$ before glucose overdose and 1/2, 1, 2 and $3 \mathrm{~h}$ after overdose. However, a level of blood glucose was performed just before the overdose $(\mathrm{t}=0$ hours $)$.

Antidiabetic effect of the aqueous extract in rats made diabetic by injection of streptozotocin.

Diabetic rats were fasted for 16 hours and then divided into five groups of 5 rats each one and treated orally as follow: group 1 received $10 \mathrm{ml} / \mathrm{kg}$ of distilled water (negative control); group $2,5 \mathrm{mg} / \mathrm{kg}$ of glibenclamide (positive control); group 3, 4 and 5 respectively 200, 400 and $800 \mathrm{mg} / \mathrm{kg}$ of extract. Glucose intake in all rats was made before administration of the different products $(\mathrm{t}=0$ hours). After the administration of the products, the blood glucose levels were taken 1, 2, 3, 4 and 5 hours after.

Evaluation of the wound healing activity by ointments of aqueous and hydroethanolic extracts.

The incision wounds of around $1 \mathrm{~cm}^{2}$ were made with scissors and cleaned with ethanol at $96^{\circ}$ before applying the ointments on the previously shaved back (Klotoe et al., 2014). The table 1 present the ointments composition. Wound dressing was done daily once a day with a precise dose of ointments (around $0.50 \mathrm{~g}$ ) applied to wounds cleaned with $95^{\circ}$ alcohols. The wound measurements were made every two days until complete healing. The percentage of cicatrization $(\% \mathrm{C})$ was given according to the following formula: 


$$
\text { percentage of Healing }=\frac{\text { Healed area }}{\text { Initial area }} \times 100
$$

Table 1:-Ointments composition of aqueous and hydroethanolic extract

\begin{tabular}{|l|c|c|}
\hline Product composition & Ointment A (aqueous extract) & Ointment B (hydroethanolic extract) \\
\hline Number of extracts & $5 \mathrm{mg}$ & $5 \mathrm{mg}$ \\
\hline Distilled water & $5 \mathrm{ml}$ & $5 \mathrm{ml}$ \\
\hline Vaselin & $45 \mathrm{~g}$ & $45 \mathrm{~g}$ \\
\hline Tween 80 & $5 \mathrm{ml}$ & $5 \mathrm{ml}$ \\
\hline
\end{tabular}

\section{Statistical analysis}

The results expressed affected on average of the standard mistake are submitted to an analysis of the variance to a factor followed of Student-Newman-Keuls test. The limit of significativity is fixed at $\mathrm{p}<0.05$.

\section{Results:-}

Evolution of blood glucose levels in normal rats subjected to the hyperglycemia test

The figure 1 present the evolution of glycemia level. The treated rats with the aqueous extract at 200 and $800 \mathrm{mg} / \mathrm{kg}$ do not show a reduction of average glycemia one hour afterwards. There are only those which received the glibenclamide and the extract at $400 \mathrm{mg} / \mathrm{kg}$. $30 \mathrm{~min}$ after overdose of glucose, the groups of the rats having received the extract at various doses and glibenclamide, show a lower peaks of glycemia than those having received only distilled water.

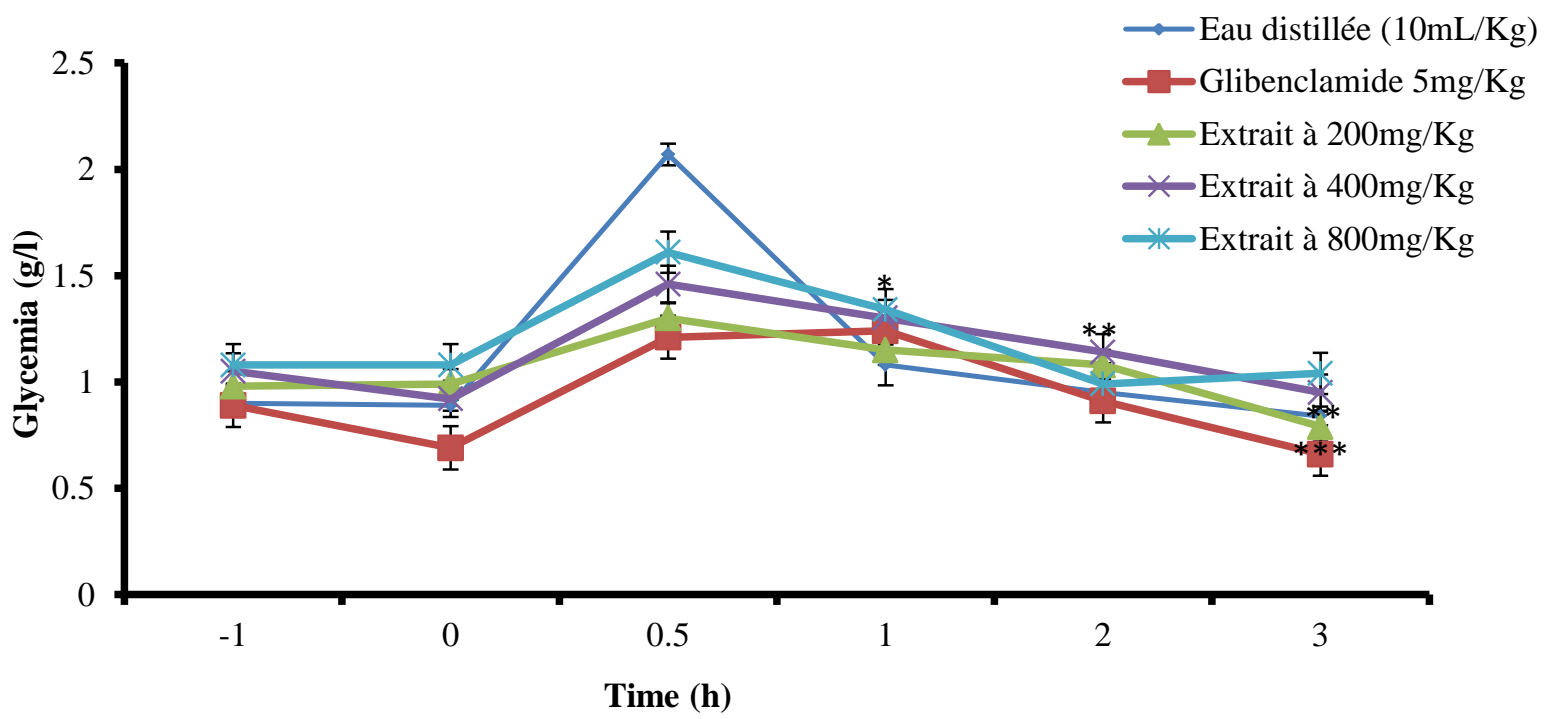

Figure 1: Evolution of glycaemia levels in normal rats tested orally induced hyperglycemia

\section{Evaluation of antidiabetic activity}

The table 2 show that the administration of distilled water significantly does not modify the basic glycemia of the rats after 5heures (1.59 \pm 0.01 with 0 hour and $1.29 \pm 0.05$ after 5 hours, corresponding to the PRG of $18.86 \%)$. The glibenclamid provoke a significant reduction of glycemia in the diabetic rats at the $1^{\text {th }}$ until the $5^{\text {th }}$ hour $(1.77 \pm 0.40$ with $0.86 \pm 0.16$, corresponding to a percentage of $51.41 \%$ ). At $200 \mathrm{mg} / \mathrm{kg}$, the extract significantly reduces the average glycemia only from the $4^{\text {th }}$ hour $(\mathrm{p}<0.05)$. At the $5^{\text {th }}$ hour the reduction becomes very significant $(\mathrm{p}<0.001)$. At $800 \mathrm{mg} / \mathrm{kg}$, the aqueous extract significantly reduced the average glycemia of the rats from the $2^{\text {nd }}$ hour, but his activity remains weak $(\mathrm{p}<0.01)$ until the $5^{\text {th }}$ hour, compared to the doses of 200 and $400 \mathrm{mg} / \mathrm{kg}$. The dose of 400 $\mathrm{mg} / \mathrm{kg}$ appeared more effective from the $2^{\text {nd }}$ until $5^{\text {th }}$ hour. 
Table 2:-effect aqueous extract of Eclipta prostrata on diabetic rats

\begin{tabular}{|c|c|c|c|c|c|c|}
\hline & \multicolumn{6}{|c|}{ Average glucose blood values (in g/l) and percentage reduction in blood glucose } \\
\hline Types of extracts & 0 hour & 1hour & 2 hours & 3 hours & 4 hours & 5 hours \\
\hline $\begin{array}{l}\text { Distilled water } \\
(10 \mathrm{ml} / \mathrm{kg})\end{array}$ & $1.59 \pm 0.01$ & $\begin{array}{l}1.59 \pm 0.06 \\
(\mathbf{0 0 . 0 0 \% )}\end{array}$ & $\begin{array}{l}1.42 \pm 0.21 \\
(\mathbf{1 0 . 6 9 \% )}\end{array}$ & $\begin{array}{l}1.36 \pm 0.10 \\
(\mathbf{1 4 . 4 6 \% )}\end{array}$ & $\begin{array}{l}1.30 \pm 0.06 \\
(\mathbf{1 7 . 6 1 \% )}\end{array}$ & $\begin{array}{l}1.29 \pm 0.05 \\
(\mathbf{1 8 . 8 6 \% )}\end{array}$ \\
\hline $\begin{array}{l}\text { Glibenclamide } \\
(5 \mathrm{mg} / \mathrm{kg})\end{array}$ & $1.77 \pm 0.40$ & $\begin{array}{l}1.01 \pm 0.22 \\
(42.93 \%) *\end{array}$ & $\begin{array}{l}0.95 \pm 0.22 \\
(\mathbf{4 5 . 7 6 \% ) * *}\end{array}$ & $\begin{array}{l}0.76 \pm 0.17 \\
(\mathbf{5 7 . 0 6 \% ) * *}\end{array}$ & $\begin{array}{l}0.78 \pm 0.10 \\
(55.93 \%) * *\end{array}$ & $\begin{array}{l}0.86 \pm 0.16 \\
(\mathbf{5 1 . 4 1 \%} \% * *\end{array}$ \\
\hline $\begin{array}{l}\text { Aqueous extract } \\
(200 \mathrm{mg} / \mathrm{kg})\end{array}$ & $1.60 \pm 0.10$ & $\begin{array}{l}1.50 \pm 0.07 \\
(6.25 \%) \mathbf{n s}\end{array}$ & $\begin{array}{l}1.51 \pm 0.05 \\
(\mathbf{5 . 6 2 \%}) \mathrm{ns}\end{array}$ & $\begin{array}{l}1.44 \pm 0.10 \\
(\mathbf{1 0 \%}) \mathbf{n s}\end{array}$ & $\begin{array}{l}1.37 \pm 0.10 \\
(\mathbf{1 4 . 3 7 \%}) *\end{array}$ & $\begin{array}{l}1.21 \pm 0.04 \\
(\mathbf{2 4 . 3 7 \%} \% * * *\end{array}$ \\
\hline $\begin{array}{l}\text { Aqueous extract } \\
(400 \mathrm{mg} / \mathrm{kg})\end{array}$ & $1.63 \pm 0.12$ & $\begin{array}{l}1.51 \pm 0.08 \\
(7.97 \%) \mathrm{ns}\end{array}$ & $\begin{array}{l}1.44 \pm 0.06 \\
(\mathbf{1 1 . 6 5 \%} \%\end{array}$ & $\begin{array}{l}1.38 \pm 0.02 \\
(\mathbf{1 4 . 7 2 \% ) * *}\end{array}$ & $\begin{array}{l}1.28 \pm 0.06 \\
(21.47 \%)^{* * * *}\end{array}$ & $\begin{array}{l}1.10 \pm 0.02 \\
(32.51 \%) * * *\end{array}$ \\
\hline $\begin{array}{l}\text { Aqueous extract } \\
(800 \mathrm{mg} / \mathrm{kg})\end{array}$ & $2.77 \pm 0.58$ & $\begin{array}{l}2.17 \pm 0.34 \\
(\mathbf{2 1 . 6 6 \% ) n s}\end{array}$ & $\begin{array}{l}1.85 \pm 0.15 \\
(33.21 \%)^{*}\end{array}$ & $\begin{array}{l}1.70 \pm 0.15 \\
(38.62 \%)^{* *}\end{array}$ & $\begin{array}{l}1.45 \pm 0.11 \\
(47.65 \%)^{* *}\end{array}$ & $\begin{array}{l}1.37 \pm 0.10 \\
(\mathbf{5 0 . 5 4 \%}) * *\end{array}$ \\
\hline
\end{tabular}

The results are expressed as mean \pm standard deviation with $\mathrm{n}=4$; ns $=$ not significant

$* \mathrm{p}<0.05 ; * * \mathrm{p}<0.01 ; * * * \mathrm{p}<0.001$ significant difference compared to controls.(...): percentage reduction in blood glucose

\section{Evaluation of wood healing activity of aqueous and hydroethanolic extracts}

The effect of the ointment of the aqueous (A) and hydroethanolic (B) extracts are presented by figure 4. One observe that the treatment with Cicatryl and the ointment (A and B) decreases the the wounds diameters of the animals compared to the wounds of the treated animals with vaselin. However, at the $8^{\text {th }}$ day (J8), one notes a weak reduction in the treated animals with cicatryl that those treated with the ointment (A and B) compared to vaselin. At J8, these diameters are $100 \%$ for vaselin, 100,5\% for Cicatryl, 73,75\% for ointment A and 90,25\% for the ointment B. These results show also that the treated animals with ointment $\mathrm{A}$ heal better the wounds of incision that those treated with the pomade B, Cicatryl and vaselin. In addition, the wounds of the animals treated with the ointment A and B completely healed in $\mathrm{J} 14$ compared to those treated with cicatryl (J16) and vaselin (J18).

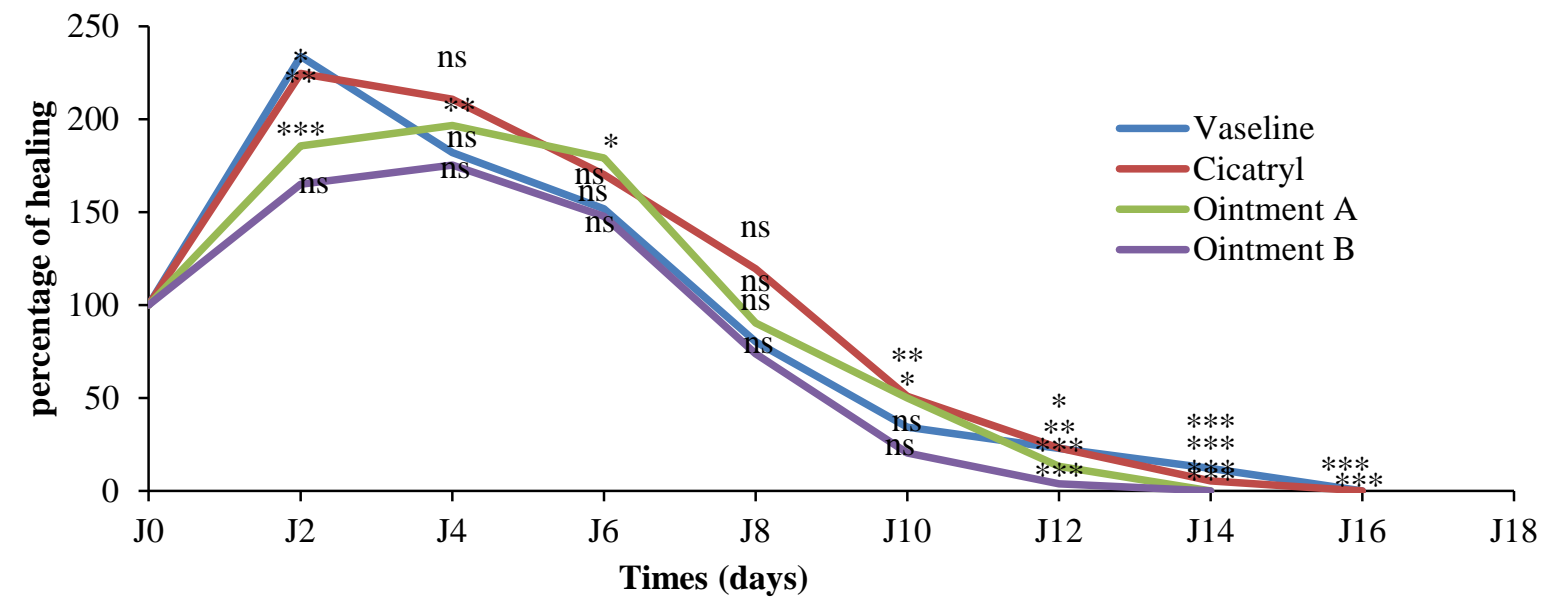

Figure 4:-Effect of the two ointments (A and B) on the diameter of the incision wounds in the rat. Each value represents the average plus or minus standard error of the percentage wounds healing $(\mathrm{P})$.

\section{Discussion:-}

E. prostrata is a plant widely used in the treatment of several affections which the diabetes, wounds, arterial hypertension, diarrhoea and abdominal pains (Ahombo and al., 2012). At the date, no scientific data exists to support the antidiabetic and wound healing activities as claimed by rural populations; thus we proposed to evaluate the antidiabetic and wound healing properties extracts of the leaves in the rat.

The experimentation reveal that, the aqueous extract significantly reduced the glycemia as well in the rats hyperglycemic as in the rats made diabetic by injection of the streptozotocin. The glucose tolerance test by oral way, shows that the extract has a protective effect against occurred of the hyperglycemia due to the overdose of glucose. The figure 3 shows that the administration of the aqueous extract $(200,400$ and $800 \mathrm{mg} / \mathrm{kg})$, one hour before the 
overdose of glucose, prevents the increases of glycemia to the breaking values, compared to the animals of control group (distilled water) which make high hyperglycemia. Indeed, the animals having received the aqueous extract at various doses present $30 \mathrm{~min}$ after the overdose of glucose, the lower peaks of glycemia than those of the rats having received only distilled water. These results are similar to those obtained with other plants (Ampa et al., 2013 ; Ndomou et al., 2014 ; Ampa et al., 2018).

Table 2 shows that the aqueous extract $(400$ and $800 \mathrm{mg} / \mathrm{kg})$ reduce significantly $(\mathrm{p}<0.05)$ the average of glycemia in the diabetic rats from the $2^{\text {nd }}$ until the $5^{\text {th }}$ hour where the effectiveness remains and becomes more significant $(\mathrm{p}<0.01$ at $800 \mathrm{mg} / \mathrm{kg}$ and $\mathrm{p}<0.001$ at $400 \mathrm{mg} / \mathrm{kg}$ ). The dose of $200 \mathrm{mg} / \mathrm{kg}$ becomes significantly effective only from the $4^{\text {th }}$ hour. These results suggest that the antidiabetic activity of the aqueous extract of E. prostrata is dosedependent and the dose of $400 \mathrm{mg} / \mathrm{kg}$ seems to be the better. These results let think that aqueous extract of $E$. prostata contain bioactives substances which would be responsible of this activity. Indeed, a former phytochimical study had already revealed the presence of polypeptids, sterols, triterpens, tanins, carotenoids, flavonoids, polypeptids, coumarins, polyuronids, mucilage and heterosids (Sissoko, 2012). Thus this antidiabetic activity of $E$. prostrata can probably be allotted to the flavonoids. This compound are known as a regulator of glycemia in rats (Ampa et al., 2017).

The second goal of this study was to evaluate the wound healing capacity. In oder to confirm the results, we use the ointments of aqueous and hydroethanolic extract; and vaselin as excipient in the formulation for his skin lenitive property. The macroscopic observation of the wounds show that the process of cure proceeded in several phases : a phase of progressive disappearance of inflammation (wounds became less red), a phase of contraction (the wounds became hard and covered a little black crusts). The treatment allowed a complete cure of the wounds (figure 4). The significant difference between the treated group and the control group was obtained between J6 and J16 would be related to the healing effect of E. prostrata. This period would correspond to the proliferative phase and, epithelialisation of the cicatricial process which is characterized by the granulation and epithelialisation phenomenon (Bensegueni et al., 2007). The healing capacity of E. prostrata would be related to the effects of various chemical compounds (Korotimi, 2010 ; Klotoé et al., 2012)

\section{Conclusion:-}

The results of this study let conclude that the leaves of E prostata have antidiabetic and wound healing properties. These results would justify the use of this specie in the treatment of diabetes and wounds in traditional medicine. In the light of the results obtained, it would be judicious to research toxicity of the extracts.

\section{References:-}

1. Hajzadeh, M., Rajaci, Z., Ghamami, G., Tamiz, A. (2011). The effect of Salvia officinalis leaf Extract on Blood Glucose in Streptozocin-Diabetics. Pharmacology Online, 1, 213-220.

2. Sambo, M.H. (2011). Diabetes Atlas, 5th edition. International Diabetes Federation, 36.

3. Diabaction Congo Association, (2015). Epidemiology of Diabetes in Congo Brazzaville. Africa news, 10.

4. Grimaldi, A., Cornet, P., Masse-Boeuf, N., Popetier, M., Sachon, C. (1997). Guide Practice of diabetes. Editions Mimi, Paris, 136.

5. Nissen, S.E., Wolski, K. (2007). Effect of Rosiglitazone on the risk of mycardial infarction dearth from cardiovascular causes. New England Journal of Medicine, 356, 2457-2471.

6. Nissen, S.E. (2010). Setting the record straits. Journal of the American Medical Association, 303, 1194-1195.

7. WHO, 2008. Diabetes. Media Center. Memorandum $\mathrm{N}^{\mathrm{o}} .312$.

8. Dithala, S., Kiranmai, M., Dorababu, N., Mohammed, I. (2012). Pharmacognostical, phytochemical and analgesic activity of eclipta prostrata. 1 (Asteraceae). Journal of Global Trends in Pharmaceutical Sciences, 3, (3), 740-746.

9. Mohamed, S.G.A and Nalini D. (2015). Activity of Methanolic extract of Eclipta prostrata (L.) L. International Journal of Phytopharmacy, 5, (2): 21-24.

10. Tewtrakul, S., Subhadhirasakul, S., Tansakul, P., Cheenpracha, S. (2011). Antiinflammatory constituents from Eclipta prostrata using. RAW264.7. Macrophage cells. Phytotherapy Research. 25,(9): 1313-6.

11. Ahombo, G., Ampa, R., Diatewa, M., Abena, A.A., Ouamba, J.M. (2012). Investigation on related diabetic seedlings used in traditional medicine at Brazzaville. Journal of Medical Plants Research, 6,(44), 5630-5639. 
12. Tedong, L., Dzeufiet-Djomeni, D.P., Dimo, T., Asongalem, A.E., Sokeng, S.N., Flejou, F.J., Callard, P., Kamtchouing, P. (2007). Effect of hexane extract of leaves of western Anacardium L. (Anacardiaceae) on the function of reproduction in rats made diabetic by streptozotocin. Phytotherapy, 5, 182-193.

13. Klotoe, J.R., Dougnon, T.V., Dougnon, T.J., Agbodjento, E., Ategbo, J.M. and Loko, F. (2014). Jatropha multifida Linn (Euphorbiaceae): Exploration properties

14. Ampa, R., Ahombo, G., Nguimbi, E., Diatewa, M., Dimo, T., Ouamba, M.J., Abena, A.A. (2013). Evaluation of hypoglycemic, antihyperglycemic and antidiabetic properties of Triplesium madagascarienses D.C. Leuwenberg (Moraceae). E3 Journal of Biotechnology and Pharmaceutical Research, 4, (3), 48-53.

15. Ndomou, M., Djidjou, K.P., Ayong, N.H., Gouado, I., Tchregang, C. (2014). Activity evaluation antidiabetic agents of the leaves of Gnetum africanum and Gnetum bulchozzianum (Gneceae) 15, 60-65.

16. Ampa, R., Morabandza, C.J., Okoumou, G.M.S., Diatewa, M. Ongoka, P. R. and Abena, A.A. (2018). Antidiabetic activity and chemical screening of the aqueous extract of seeds of strychnos camptoneura gilg \& busse (loganiaceae). World Journal of Pharmaceutical Research,7, (18), 322-332.

17. Sissoko, F.K. (2012). Study of the phytochemistry and biological activities of Musa acuminata, Mangifera index, Boerha via erecta and Eclipta prostrata. These pharmacy, 138.

18. Ampa, R., Morabandza, C.J., Ahombo, G., Nguimbi, E., Diatewa, M., Abena, A.A., Dimo, T., Ouamba, J.M. (2017). Prevention of diabete complications by hydro-ethanolic extract of the leaves of trilepisium madagascariense Leeuwenberg D.C. (Moraceae). World journal of pharmacy and pharmaceutical sciences, 6, (11), 855-866.

19. Bensegueni, A. (2007). Traditional ointments in the treatment of wounds and burns. State Thesis in Veterinary Science. Mebtouri University. Constantine, 21-22.

20. Korotimi, D.A.K. (2010). Healing properties of the leaves of Opitia celtidifolia (Guill and Perr) Endl. Ex Walp (Opiliaceae). Pharmacy thesis. University of Bamako. Faculty of Medicine Pharmacy and Odonto Stomatology, 109. 